\title{
Trunk Disease Fungi Associated With Diospyros kaki in South Africa
}

P. Moyo, L. Mostert, and M. Bester, Department of Plant Pathology, University of Stellenbosch, Private Bag X1 Matieland, 7602, South Africa; and F. Halleen, Department of Plant Pathology, University of Stellenbosch, Private Bag X1 Matieland, 7602, South Africa, and Plant Protection Division, ARC Infruitec-Nietvoorbji, Private Bag X5026, Stellenbosch, 7599, South Africa

\begin{abstract}
Moyo, P., Mostert, L., Bester, M., and Halleen, F. 2016. Trunk disease fungi associated with Diospyros kaki in South Africa. Plant Dis. 100:2383-2393.

Persimmon trees with dieback symptoms and cankers were observed in three production areas in Western Cape Province in South Africa. Isolations were made from diseased branches, cankers, and pruning wounds as well as fungal fruiting bodies on dead branches and old pruning wounds. Several trunk disease pathogens were identified based on morphological characteristics and by molecular methods, including Diaporthe eres, D. infecunda, Eutypella citricola, E. microtheca, Phaeoacremonium parasiticum, P. scolyti, P. australiense, P. minimum, Fomitiporia capensis, Fomitiporia sp., Fomitiporella sp., and Inocutis sp., which were isolated

from persimmon for the first time in the world. Other first reports from persimmon in South Africa include D. foeniculina, D. ambigua, D. mutila, Diaporthe sp., Neofusicoccum australe, N. parvum, Diplodia seriata, and Eutypa lata. Pathogenicity tests conducted with all species, except the basidiomycetes, confirmed their status as possible persimmon pathogens. This is the first study to determine and identify fungi associated with diseased persimmon in South Africa. The knowledge gained in this study forms the basis for further research to determine the impact of these fungi on persimmon productivity.
\end{abstract}

Persimmon (Diospyros kaki Thunb., family Ebenaceae) is a deciduous tree native to China, with a world production of approximately 4,637,357 tons from 819,167 hectares in the year 2013 (Food and Agricultural Organization of the United Nations Statistics Division [FAOSTAT] faostat.fao.org). Persimmon fruit is largely produced by China (3,618,823 tons), Korea (351,990 tons), and Japan (214,700 tons), but a sizeable amount is also produced in countries such as Brazil, Australia, New Zealand, Italy, and Israel (FAOSTAT; Llácer and Badenes 2002; Tous and Ferguson 1996). Persimmon production in South Africa is still in its infancy. Persimmon was introduced commercially in 1998 and is mostly cultivated in the Mediterranean regions of Western Cape Province, where approximately 400 hectares are grown (Post-Harvest Innovation [PHI] database, http://www. postharvestinnovation.org.za/projects-2). The most important persimmon cultivar planted in South Africa is 'Triumph', which is marketed as sharon fruit. Approximately 7,000 tons of persimmon fruit are produced annually in South Africa (Nunez and Bruins 2013) and most of the yield is exported. The export market includes countries such as Singapore, Canada, and Malaysia, but the largest export market is Germany (PHI database). Although low quantities are produced in comparison with other countries in the world, persimmon export serves as an additional source of income to the South African economy. Furthermore, South Africa serves as an off-season supplier of persimmon fruit to the Northern Hemisphere (ARISA 2015). The older orchards (15 years) are now beginning to show dieback symptoms and cankers, and it is, therefore, important to investigate possible pathogens that may contribute to this phenomenon and hinder the production of persimmon in South Africa.

A number of trunk disease pathogens have been reported as pathogens of fruit trees worldwide (Carlucci et al. 2015; Cloete et al. 2011; Crous et al. 2000, Damm et al. 2008; Gramaje et al. 2012; Slippers et al. 2007; Smit et al. 1996; Uddin et al. 1998); however, none of these have been associated with persimmons in South Africa. The main groups of trunk disease pathogens affecting grapevines, stone, and pome fruit, which are the major fruit crops grown in Western Cape Province, include species in families Botryosphaeriaceae,

Corresponding author: F. Halleen; E-mail: halleenf@arc.agric.za

Accepted for publication 21 June 2016.

http://dx.doi.org/10.1094/PDIS-02-16-0245-RE

(C) 2016 The American Phytopathological Society
Diatrypaceae, and Togniniaceae, and order Diaporthales. Trunk disease pathogens attack woody parts of the host, causing symptoms such as cankers, shoot blights, dieback, and internal symptoms including wedge-shaped necrosis as well as black or brown streaking in the vascular tissues (Larignon et al. 2001; Moller and Kasimatis 1981; Uddin et al. 1998; White et al. 2011a). These pathogens mainly invade plants through openings such as pruning wounds (English and Davis 1978; Eskalen et al. 2007; van Niekerk et al. 2011) and sucker wounds (Makatini 2014). Spores of trunk pathogens are aerially dispersed and arthropods have been found to carry spores in vineyards (Moyo et al. 2014). The abnormalities caused by trunk disease fungi lead to lower yield and quality of fruits, which ultimately impacts the amount of income for producers. The aim of this study was to identify trunk disease fungi associated with dieback and cankers on persimmon trees in Western Cape Province of South Africa and to evaluate their status as pathogens on this host by conducting pathogenicity studies on field-grown trees.

\section{Materials and Methods}

Sampling and collection of fungal isolates. In 2013, field surveys were conducted in three of the persimmon-producing areas in Western Cape Province, namely, Stellenbosch, Franschhoek, and Bonnievale. Pruning wounds and symptomatic wood from shoots and branches showing dieback and cankers were collected from five persimmon orchards ('Triumph'), aged between 10 and 15 years. In every orchard, 10 symptomatic wood pieces were collected (from 10 different trees), taken to the laboratory, and dissected and processed or stored at $4{ }^{\circ} \mathrm{C}$ for processing within 2 days. Wood pieces bearing fruiting bodies were also examined microscopically.

Upon dissection of wood samples, disease symptoms were photographed, described, and marked. The wood pieces were first surfacesterilized in $70 \%$ ethanol for $30 \mathrm{~s}$, followed by $2 \mathrm{~min}$ in $3 \% \mathrm{NAOCl}$ and $30 \mathrm{~s}$ in $70 \%$ ethanol. Twelve pieces (approximately $2 \times 2 \mathrm{~mm}$ ) were cut from the margin of healthy and diseased tissue of each symptom type. Four pieces of wood were plated on one plate of potato dextrose agar (PDA) (Biolab) amended with chloromycetin ( $250 \mathrm{mg} / \mathrm{liter})$. All plates were incubated at $24^{\circ} \mathrm{C}$ and were exposed to approximately $12 \mathrm{~h}$ of daylight and $12 \mathrm{~h}$ of darkness for up to 4 weeks. Hyphae of possible pathogens growing from the wood were transferred to fresh PDA plates for further identification and characterization. Fungal identification was achieved by using morphological characteristics and DNA-based methods as described below. Isolates collected during the study were stored in the culture collection of the Department of Plant Pathology at the University of Stellenbosch (STEU). 
Isolations from fruiting bodies were achieved by cutting the stromata open under a stereomicroscope (Nikon SMZ 1500), revealing the perithecial contents, and adding a drop of sterile water on the opened perithecia (Trouillas et al. 2010). Perithecial contents were then collected with a needle, were mounted in water on a microscopic slide, and were examined under a light microscope (Nikon Y-TV55) for morphological identification. Thereafter, $30 \mu l$ of sterile water was mixed with the contents of the slides and cover slips by pipetting. This mixture was then transferred onto water agar in petri dishes. Images were captured with a Nikon DS-Ri2 camera on a Nikon light microscope at 1000× magnification. Within 2 days, germinating single spores were transferred to fresh PDA plates and the cultures were stored as previously described.

Morphological identification of fungal isolates. Cultural characteristics such as colony growth pattern, color, and mycelial as well as morphological characteristics including conidial shape and color were used to identify and separate trunk pathogens into their respective groups. The Botryosphaeriaceae and Diaporthales species were identified based on the descriptions made by van Niekerk et al. (2004) and Mostert et al. (2001), respectively. Descriptions by Glawe and Rogers (1984) as well as Trouillas et al. (2011) were used to identify species in the Diatrypaceae species, whereas the Togniniaceae species were identified according to Mostert et al. (2006).

DNA isolation, amplification, and sequencing of fungal isolates. The method of Damm et al. (2008) for DNA extraction was used to isolate DNA from actively growing cultures. Two gene regions were amplified for the identification of species in the families Botryosphaeriaceae, Diatrypaceae, and Togniniaceae, and order Diaporthales. Internal transcribed spacers (ITS1 and ITS2) including the 5.8S ribosomal RNA gene together with the $\beta$-tubulin gene were amplified to confirm identity of Diatrypaceaecae and Diaporthales spp., whereas the elongation factor 1- $\alpha(E F 1-\alpha)$ was targeted together with the ITS region to identify Botryosphaeriaceae species. Only the ITS region was amplified and sequenced for isolates in the Hymenochaetaceae. The Togniniaceae species were identified by amplifying the $\beta$-tubulin and actin genes, using the primers T1 (O'Donnell and Cigelnik 1997) and Bt2b (Glass and Donaldson 1995), ACT512F and ACT783R (Carbone and Kohn 1999), respectively, as described by Mostert et al. (2006).
Primer pairs ITS1/ITS4 (White et al. 1990) and Bt2a/Bt2b (Glass and Donaldson 1995) were used to amplify the ITS regions and $\beta$-tubulin gene, respectively. The $25-\mu 1$ polymerase chain reaction (PCR) reactions contained $1 \mu \mathrm{l}$ of DNA, $1 \times$ PCR buffer, $0.2 \mathrm{mM}$ dNTPs, and $0.65 \mathrm{U}$ of Bioline Taq polymerase. The ITS reaction, however, contained $2.5 \mathrm{mM} \mathrm{MgCl} 2,0.25 \mu \mathrm{M}$ each primer, and bovine serum albumen at $1 \mu \mathrm{g} / \mu \mathrm{l}$, whereas the $\beta$-tubulin PCR contained $1.5 \mathrm{mM}$ $\mathrm{MgCl}_{2}$ and $0.5 \mu \mathrm{M}$ primers. The PCR reaction conditions consisted of an initial denaturation step at $94^{\circ} \mathrm{C}$ for $5 \mathrm{~min}$, followed by 35 cycles of $30 \mathrm{~s}$ at $94^{\circ} \mathrm{C}, 30 \mathrm{~s}$ at $52^{\circ} \mathrm{C}$ (ITS), and $60^{\circ} \mathrm{C}$ ( $\beta$-tubulin), $30 \mathrm{~s}$ at $72^{\circ} \mathrm{C}$, and a final extension step at $72^{\circ} \mathrm{C}$ for $5 \mathrm{~min}$.

The amplification of EF1- $\alpha$ was performed using primers EF1728F and EF1-986R (Carbone and Kohn 1999). Each reaction contained $2 \mu \mathrm{l}$ of DNA template, $12.5 \mu \mathrm{l}$ of $2 \times$ Kappa Taq ReadyMix (KapaBiosystems), $0.4 \mu \mathrm{M}$ of each primer, and was made up to a final volume of $25 \mu \mathrm{l}$ with sterile water. PCR conditions for this region were one cycle of initial denaturation at $94^{\circ} \mathrm{C}$ for $5 \mathrm{~min}$, followed by 36 cycles of denaturation $\left(45 \mathrm{~s}\right.$ at $\left.94^{\circ} \mathrm{C}\right)$, annealing $\left(30 \mathrm{~s}\right.$ at $\left.58^{\circ} \mathrm{C}\right)$, and extension $\left(90 \mathrm{~s}\right.$ at $\left.72^{\circ} \mathrm{C}\right)$, and a final extension at $72^{\circ} \mathrm{C}$ for $6 \mathrm{~min}$.

All PCR reactions were performed in a GeneAmp PCR system 9700 (Applied Biosystems), and all PCR products were run on $1 \%$ agarose gels stained with ethidium bromide and were visualized under UV light. Estimates of amplicon sizes were made against a GeneRuler 100-bp DNA Ladder (Thermo Scientific). PCR products were cleaned using the MSB Spin PCRapase kit (Invitek). Both strands of the amplicons were sequenced, using a Big Dye Terminator v3.1 cycle sequencing ready reaction kit (PE Biosystems) with the primers used in the initial PCR reactions. The products were run on an ABI Prism 3130XL DNA sequencer (Perkin-Elmer). Species were initially identified using the megablast function of the National Center for Biotechnology Information's GenBank nucleotide database (www. ncbi.nlm.nih.gov)

Phylogenetic analyses. Phylogenetic analyses were carried out with combined ITS and $\beta$-tubulin data sets for Diatrypaceae and Diaporthales spp., whereas, for Botryosphaeriaceae spp., analysis was based on combined ITS and EF1- $\alpha$ sequence data. The $\beta$-tubulin and actin gene sequences were used to construct phylogeny of the Togniniaceae spp. Only ITS sequence data were used to reconstruct relationships for the Hymenochaetaceae spp. Depending on the number
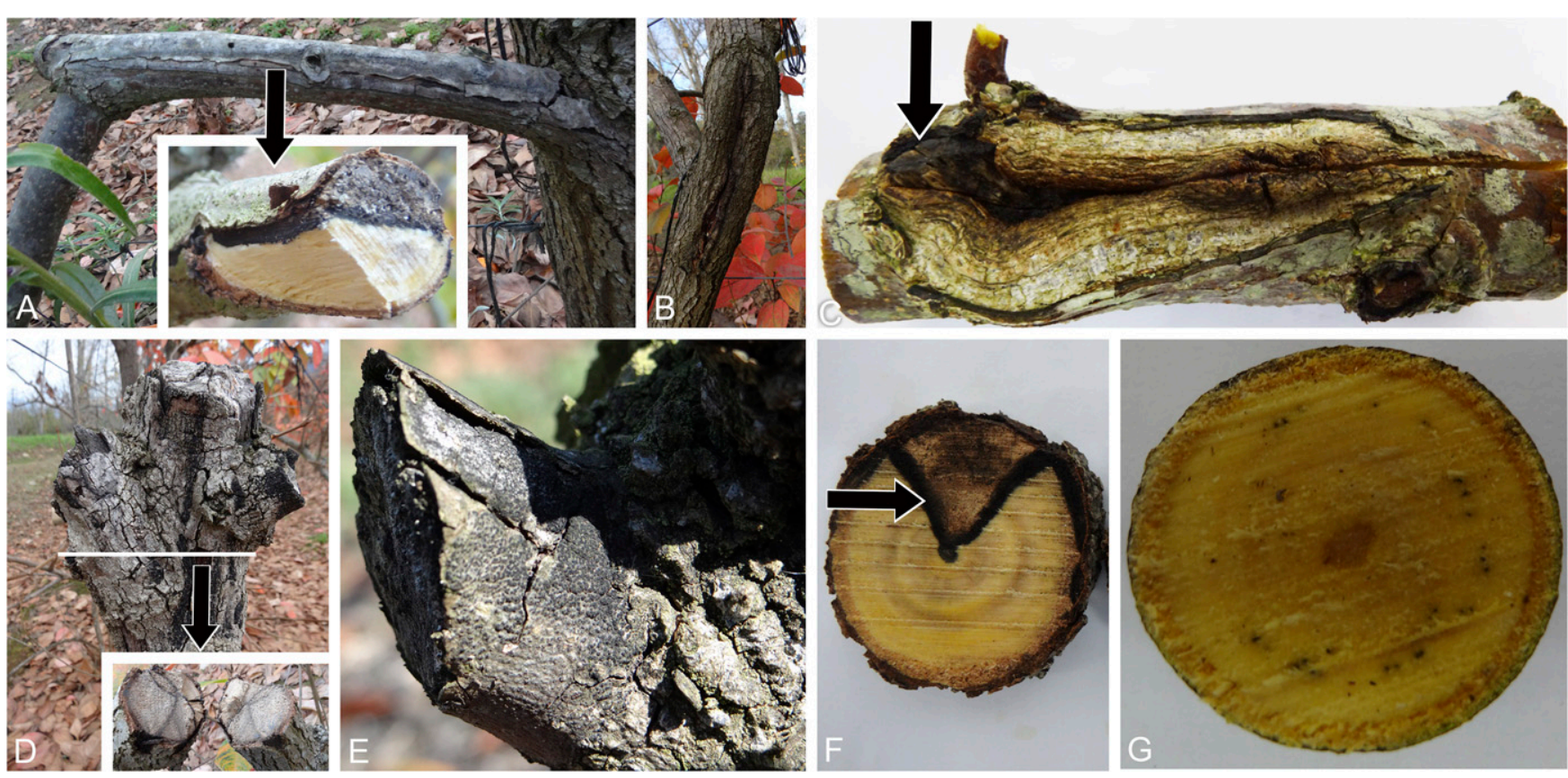

Fig. 1. Wood symptoms associated with aging persimmon trees in the Western Cape of South Africa. A, Canker on a persimmon branch and thick black lines separating infected and healthy tissue were the most prevalent symptoms observed in symptomatic wood (insert). B, Cankers were also observed on trunks. C, Cankers were observed to develop from pruning wounds (black arrow showing pruning wound). D, Dead persimmon stump with Eutypella citricola (arrow) fruiting bodies and black lines from initial infection. E, Stromata of E. citricola were observed on many pruning wounds. F, Wedge-shaped canker on a cross-sectioned branch and dark lines demarcating healthy and infected tissue (indicated by arrow). G, Black dots indicating streaking in wood. 
of isolates obtained in this study for each species within a specific fungal family, one to 13 representative isolates of each species were selected for phylogenetic analyses. The sequence data for the selected isolates, within the respective fungal groups, were aligned with sequences of taxa retrieved from GenBank, representing a selection of genera and species within the specific fungal group. The sequences for the outgroups used in the phylogenetic analyses for each fungal group were also retrieved from GenBank. The program MAFFT v7.017 (Katoh et al. 2002) in Geneious v8.1 (http://www. geneious.com) (Kearse et al. 2012) was used to align sequence data sets for all the fungal groups, and the alignment method used was L-INS-i. Maximum likelihood analyses were performed using PhyML (Guindon and Gascuel 2003) in Geneious v8.1, under the general time reversible model. Both the proportion of invariable sites and the gamma distribution parameter were estimated, and bootstrap support values were calculated from 1,000 replicates.

Pathogenicity studies. Green shoots and mature wood of fieldgrown persimmon trees ('Triumph') showing no apparent symptoms of gummosis, dieback, or weak growth were used for inoculation. These plant parts were injured with a $4 \mathrm{~mm}$ diameter cork borer and were inoculated with mycelial plugs ( $4 \mathrm{~mm}$ in diameter) of trunk disease pathogens obtained from the edge of 14-day-old cultures of each isolate grown on PDA. Sterile noncolonized PDA plugs were used to inoculate control green shoots and mature wood. Desiccation of the mycelial plugs was prevented by wrapping the wounds with Parafilm. The experiments were conducted in an incomplete block trial with 31 treatments (isolates including control) tested on 31 trees. Each tree was seen as a (incomplete) block. There were 10 replicates for each fungal isolate, and where available, up to three isolates of the same species were used for inoculation. In cases in which more than one isolate was used and depending on availability, isolates were selected from different areas. The tests were repeated in the same year and on the same farm but on two different orchards of the same age (12-year-old) and cultivar ('Triumph') but grafted on different rootstocks (Diospyros virgianiana and Diospyros kaki). The length of wood discoloration, here referred to as lesion length, produced by the different isolates was measured after 4 months and reisolations were done immediately. The reisolations were carried out by cutting the shoots longitudinally through the inoculation point and isolating from the leading edges of lesions. The isolates were confirmed as the ones used for inoculation by sequencing representative isolates. Results were analyzed in SAS (version 9.2) using General Linear Model one-way analysis of variance to determine the effects of fungal isolates on lesion length. Percentage of reisolation of fungal isolates was also determined. Fischer's least significant difference (LSD) test was then used to compare means of lesion lengths of isolates, and F values with $P<0.05$ were considered significant. The normality of the data was tested using the Shapiro-Wilk test.

\section{Results}

Sampling and collection of fungal isolates. Similar symptoms were observed in all three areas surveyed and included cankers on branches and trunks (Fig. 1A and B, respectively) as well as branch dieback. Cankers were often observed to develop from pruning wounds (Fig. 1C) and symptomatic branches often broke off leaving the trunk standing until it died (Fig. 1D). Additionally, fruiting bodies of Eutypella citricola Speg. were observed in abundance on dead wood (Fig. 1D) and old pruning wounds (Fig. 1E). The most common vascular symptoms included the well-defined black discoloration that separated the dead and live tissues (Fig. 1F). Other vascular symptoms observed included wedge-shaped necrosis (Fig. $1 \mathrm{~F}$ ) and streaking of the tissues (Fig. 1G).

A total of 120 isolates belonging to 20 species within five families were isolated. The Diaporthales species (45\%) were the most dominant fungi associated with symptoms from which isolations were made, whereas species in families Diatrypaceae (21\%) and Botryosphaeriaceae $(20 \%)$ were the second and third most predominant, respectively. More than one fungal species were isolated from a single symptom in 35 of the 50 samples (70\%) collected and the most isolated species in the study, Diaporthe foeniculina (Sacc.) D. Udayanga \& L.A
Castlebury, was found in 31 of these (89\%) samples (Table 1). The black discoloration that separated the dead and live tissues was mostly colonized by the Diaporthales spp. (54\%), followed by species from families Diatrypaceae (26\%), Botryosphaeriaceae (15\%), Togniniaceae (4\%), and class Basidiomycetes (1\%). The Diaporthales spp. (54\%) were the most frequently isolated fungal group associated with wedge-shaped necrosis followed by families Diatrypaceae $(25 \%)$ and Botryosphaeriaceae (25\%). The Diaporthales spp. (52\%) were also the most frequently isolated fungal group associated with vascular streaking followed by Basidiomycetes spp. (16\%), and species from families Diatrypaceae (12\%), Botryosphaeriaceae (12\%), and Togniniaceae (8\%).

Morphological and phylogenetic characterization. Isolates that were grouped into the genus Diaporthe according to cultural and morphological characteristics in this study were identified as belonging to five species by phylogenetic analyses of ITS and $\beta$-tubulin sequences. Most of the isolates (76\%) were identified as Diaporthe foeniculina ( $88 \%$ bootstrap support), which showed considerable sequence variation among the isolates. One isolate each of Diaporthe

Table 1. The diversity of trunk disease pathogens isolated from wood samples collected from persimmon orchards in the Western Cape Province of South Africa $^{\mathrm{Z}}$

\begin{tabular}{lr}
\hline Pathogens isolated & $\begin{array}{r}\text { No. o } \\
\text { sampl }\end{array}$ \\
\hline Satypelacitiola
\end{tabular}

Eutypella citricola samples

Diaporthe sp.

Diaporthe foeniculina

Diaporthe foeniculina + Diaporthe sp.

Diaporthe foeniculina + Diplodia seriata

Diaporthe foeniculina + Eutypella citricola

Diaporthe foeniculina + Fomitiporia capensis

Diaporthe foeniculina + Neofusicoccum australe

Diaporthe foeniculina + Fomitiporella sp.

Diaporthe foeniculina + Diaporthe sp. + Neofusicoccum australe

Diaporthe foeniculina + Diaporthe ambigua + Neofusicoccum australe

Diaporthe foeniculina + Neofusicoccum australe + Fomitiporia capensis

Diaporthe foeniculina + Neofusicoccum australe + Diplodia seriata

Diaporthe foeniculina + Eutypella citricola + Diplodia seriata

Diaporthe foeniculina + Eutypella citricola + Diaporthe $\mathrm{sp}$

Diaporthe foeniculina + Eutypella citricola + Neofusicoccum australe

Diaporthe foeniculina + Eutypella citricola + Neofusicoccum australe + Fomitiporia sp.

Diaporthe foeniculina + Eutypella citricola + Fomitiporia capensis + Inocutis sp.

Diaporthe foeniculina + Eutypella citricola + Eutypa lata + Fomitiporia capensis

Diaporthe foeniculina + Eutypella citricola + Neofusicoccum australe + Phaeoacremonium parasiticum

Diaporthe foeniculina + Eutypella citricola + Diaporthe infecunda + Phaeoacremonium scolyti

Diaporthe foeniculina + Eutypella citricola + Eutypella microtheca + Neofusicoccum australe + Phaeoacremonium parasiticum

Diaporthe foeniculina + Diaporthe sp. + Diaporthe eres + Neofusicoccum australe + Phaeoacremonium australiense

Diaporthe foeniculina + Diplodia seriata + Diaporthe $\mathrm{sp} .+$ Eutypella citricola + Phaeoacremonium scolyt $i$

Diaporthe foeniculina + Diaporthe $\mathrm{sp} .+$ Eutypa lata + Eutypella citricola + Neofusicoccum australe + Phaeoacremonium scolyti

Eutypella citricola + Neofusicoccum parvum

Eutypella citricola + Fomitiporia capensis

Eutypella citricola + Phaeoacremonium minimum

Diaporthe sp. + Diplodia seriata + Fomitiporia capensis + Fomitiporella sp.

Total number of samples collected

13

2

1

3

1

2

1

1

1

2

1

1

1

${ }^{\mathrm{z}}$ Trunk disease pathogens were isolated from all samples. 
infecunda R.R. Gomes, C. Glienke \& Crous, D. eres (Nitschke), and D. ambigua (Nitschke) were also found with 75,100 , and $100 \%$ bootstrap support, respectively. These three species contributed $2 \%$ each to the total number of isolates within the genus Diaporthe. Isolates of the fifth species were within a clade containing three species (namely D. amydgali, D. ovoicicola, and D. fusicola) and their relationships could not be resolved with the two gene regions used in this study (Fig. 2) and these contributed $18 \%$ of the isolates in this fungal group. Resolving the taxonomy of the genus Diaporthe was outside the scope of this study and, thus, the isolates within this clade are herein referred to as Diaporthe sp. (79\% bootstrap support).

Four of the Botryosphaeriaceae species were identified based on phylogenetic analysis of ITS and EF1- $\alpha$ sequence data. The species are Neofusicoccum australe (Slippers, Crous \& M.J. Wingf.) Crous, Slippers \& A.J.L. Phillips (100\% bootstrap support), Neofusicoccum parvum (Pennycook \& Samuels) Crous, Slippers \& A.J.L. Phillips

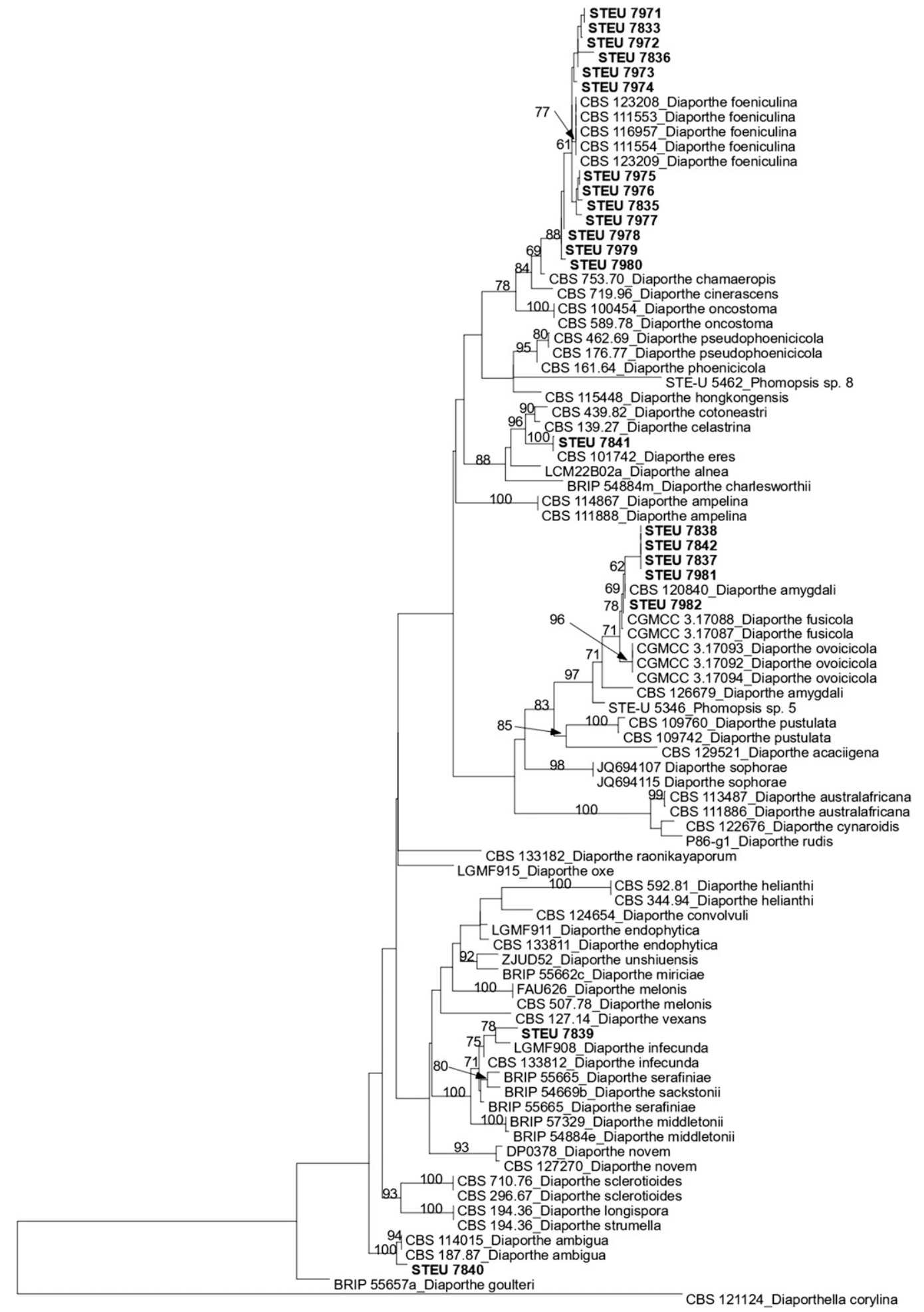

0.2

Fig. 2. Maximum likelihood phylogenetic tree of Diaporthe species based on internal transcribed spacer and $\beta$-tubulin sequence data. Bootstrap support values were calculated from 1,000 replicates and bootstrap support values $<60 \%$ are not shown. Diaporthella corylina was used as an outgroup and isolates obtained in the current study are in bold 
(98\% bootstrap support), Diplodia mutila (Fr. :Fr.) Mont (98\% bootstrap support), and Diplodia seriata De Not. (98\% bootstrap support) (Fig. 3). Most of the isolates belonged to N. australe (71\%), followed by $D$. seriata (21\%), whereas $N$. parvum and D. mutila contributed $4 \%$ each to the total number of isolates within the Botryosphaeriaceae spp.

Phylogenetic analysis of the isolates that were grouped as belonging to family Diatrypaceae by means of cultural characteristics revealed that most of the isolates (88\%) belonged to Eutypella citricola Speg. (77\% bootstrap support), two isolates were identified as Eutypa lata (Pers.) Tul. \& C. Tul. (100\% bootstrap support), and one isolate was confirmed to be Eutypella microtheca Trouillas, W.M. Pitt \& Gubler by bootstrap support of $92 \%$ (Fig. 4).

The phylogeny of the Togniniaceae spp. is shown in Figure 5 and is based on the combined data set of $\beta$-tubulin and actin genes. Isolates were identified as belonging to four species. The most frequently found (43\%) species was Phaeoacremonium scolyti L. Mostert, Summerb. $\&$ Crous ( $98 \%$ bootstrap support) followed by Phaeoacremonium parasiticum (Ajello, Georg \& C.J.K. Wang) W. Gams, Crous \& M.J. Wingf. (100\% bootstrap support), which were $29 \%$ of the total isolates in the group. Both Phaeoacremonium australiense L. Mostert, Summerb. \& Crous (100\% bootstrap support) and Phaeoacremonium minimum (Tul. \& C. Tul.) D. Gramaje, L.Mostert \& Crous (100\% bootstrap support) (Fig. 5) contributed $14 \%$ each to the total number of isolates.

Isolates that were grouped as belonging to family Hymenochaetaceae were analyzed phylogenetically, based on ITS sequence data only, and the analysis revealed the isolates to belong to four species, namely Fomitiporia capensis M. Fisch., M. Cloete, L. Mostert \& F. Halleen (98\% bootstrap support), Fomitiporella sp. (Taxon 1) (White et al. 2011b) (100\% bootstrap support), a Fomitiporia sp. (91\% bootstrap support) that is closely related to $F$. mediteranea, and an Inocutis sp. (Taxon 3) (White et al. 2011b) that had 100\% bootstrap support (Fig. 6). Fomitiporia capensis was the most dominant species $(64 \%)$ in this group, followed by Fomitiporella sp. (18\%) and Fomitiporia sp. and Inocutis sp. (9\% each).

Microscopic examination of the fruiting bodies collected from dead wood pieces of persimmon revealed that the stromata was mostly in the bark, with sulcate ostioles protruding through the bark surface (Fig. 7A). The slicing of the stromata revealed perithecia to be surrounded by white powdery entostroma (Fig. 7B) and, on mounting the perithecial contents on a microscopic slide, the asci were found to be clavate and octosporous, with allantoid ascospores (Fig. 7C). Colonies were white with moderate aerial mycelium on

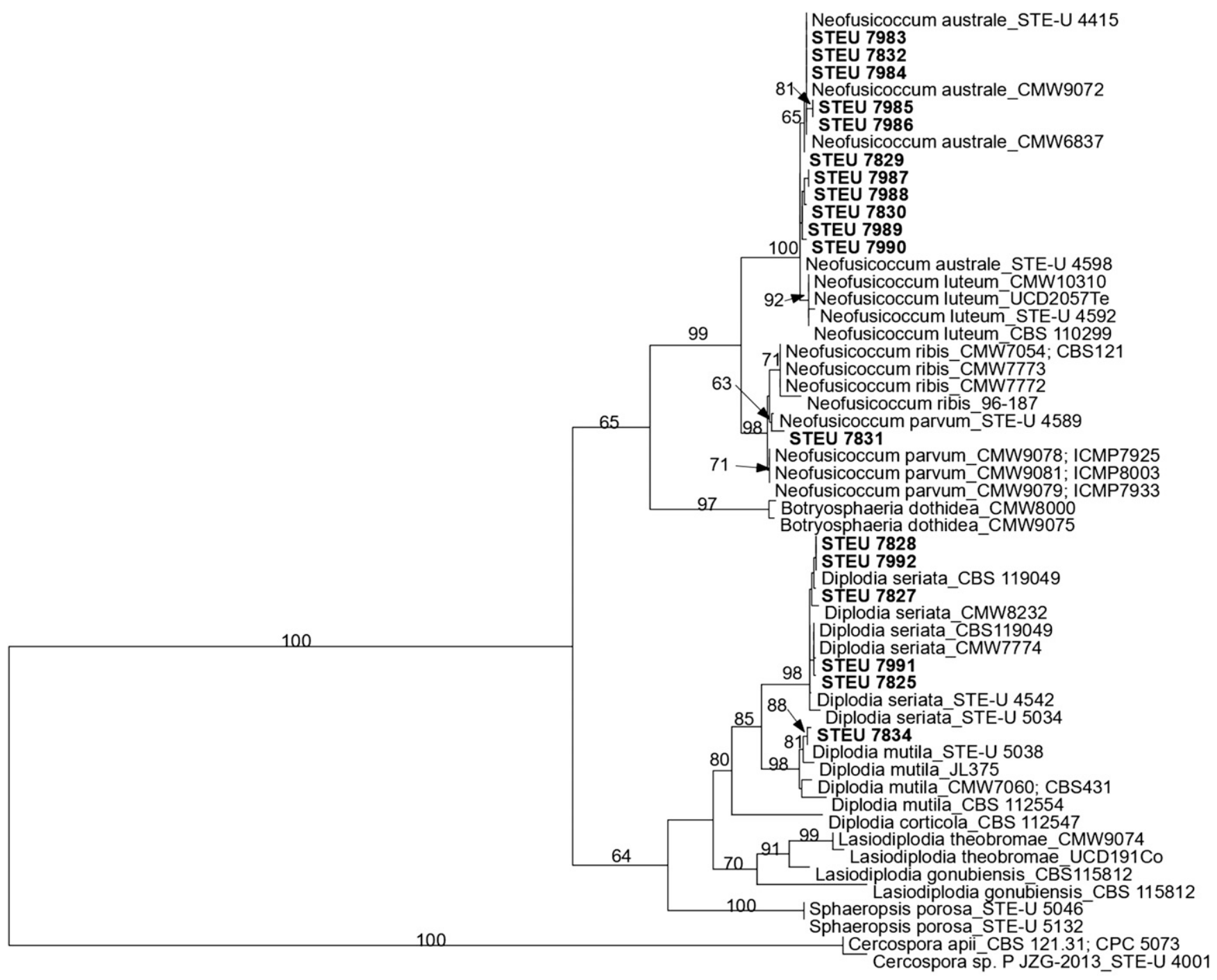

0.2

Fig. 3. Maximum likelihood phylogenetic tree of species in family Botryosphaeriaceae, based on internal transcribed spacer and EF1- $\alpha$ sequence data. Bootstrap support values were calculated from 1,000 replicates and bootstrap support values $<60 \%$ are not shown. Cercospora spp. were used as outgroups and isolates obtained in the current study are in bold. 
PDA. These morphological traits identified the fungus as belonging to the family Diatrypaceae (Glawe and Rogers 1984; Trouillas et al. 2011). The species was confirmed as E. citricola by PCR amplification and sequencing of the ITS region as well as the $\beta$-tubulin gene.

Pathogenicity studies. Inoculation of mature wood and green shoots of persimmon trees always resulted in wood discoloration after 4 months of incubation (Table 2). In the trial in which mature wood was inoculated, no significant differences were observed among the blocks in orchards 1 and $2(P=0.3009$ for orchard 1 and $P=0.8217$ for orchard 2). However, significant differences $(P<0.0001)$ in mean lesion lengths caused by the different isolates were evident between the two orchards. Persimmon trees in orchard 1 were grafted on the rootstock Diospyros kaki, while Diospyros virginiana was used as the rootstock for trees in orchard 2. Most of the isolates produced longer lesions in orchard 2 compared with orchard 1. For this reason, mean lesion lengths caused by the different isolates are reported separately for the two orchards (Table 2). Furthermore, mean comparison tests for lesion length also showed that there were significant differences in discoloration caused by individual isolates in each orchard $(P=0.0006$, orchard $1 ; P=0.0093$, orchard 2$)$. Mean lesion length ranged from $30.68 \mathrm{~mm}$ for $D$. infecunda to $53.92 \mathrm{~mm}$ for E. microtheca in orchard 1, whereas, in orchard 2, mean lesion length ranged from $36.71 \mathrm{~mm}$ for D. foeniculina (STEU 7835) to $65.17 \mathrm{~mm}$ for $P$. australiense. In orchard 1, E. citricola (STEU 7813), D. foeniculina (STEU 7835), N. australe (STEU 7830), and $D$. infecunda produced lesions that were not significantly different

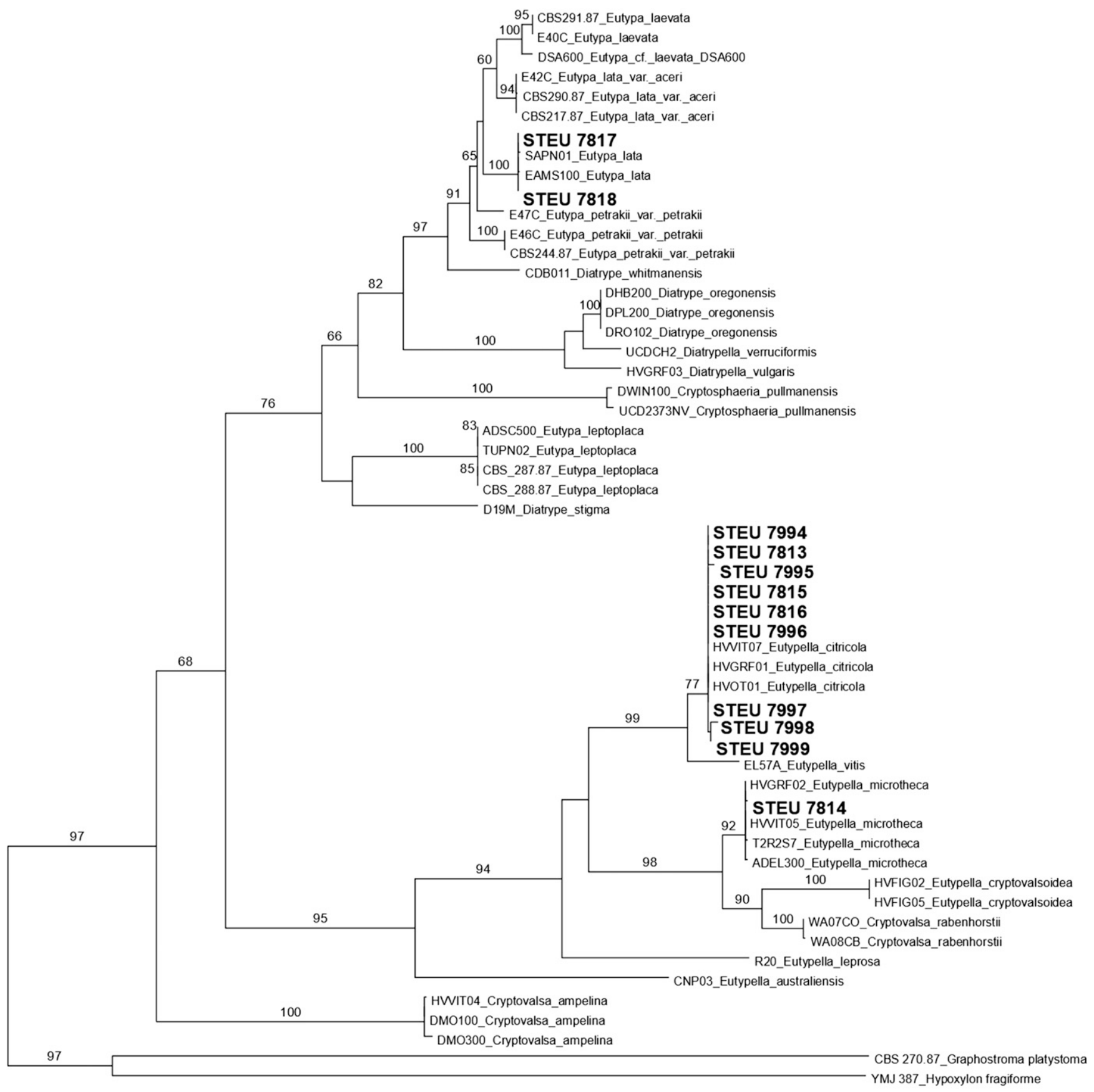

Fig. 4. Maximum likelihood phylogenetic tree of Diatrypaceae species based on internal transcribed spacers and $\beta$-tubulin sequence data. Bootstrap support values were calculated from 1,000 replicates and bootstrap support values $<60 \%$ are not shown. Gaphostroma platystoma and Hypoxylon fragiforme were used as outgroups and isolates obtained in the current study are in bold. 
from those of the control. Diaporthe foeniculina (STEU 7835) was the only isolate that produced lesions not significantly different from the control in orchard 2. Isolates within species, however, behaved similarly in both orchards, with the exception of $D$. foeniculina (STEU 7835) and N. australe (STEU 7830), which produced shorter lesions compared with D. foeniculina (STEU 7833) and N. australe (STEU 7832), respectively in orchard 1.

Fungal isolates were able to colonize mature wood of persimmon, with all isolates being reisolated and identified from inoculated wood, 4 months post inoculation. Furthermore, a number of species were able to produce the well-defined black lesions similar to those observed and collected from the orchards during surveys. For orchard 1 , percentage recovery of fungal isolates from inoculated wood ranged from $50 \%$ for E. microtheca to $100 \%$ for several isolates, including all D. foeniculina isolates, D. ambigua, Diaporthe sp. (isolates STEU 7837 and STEU 7842), P. australiense, $P$. scolyti (STEU 7822), Eutypa lata (STEU 7818), N. parvum, Diplodia seriata (STEU 7825, STEU 7828), and N. australe (STEU 7829). Lowest percentage recovery from inoculated wood was obtained for E. microtheca (10\%), E. citricola isolate STEU 7815 (30\%), Eutypa lata isolate STEU 7817 (40\%), and E. citricola isolate STEU 7813 (40\%) in orchard 2. Highest percentage recovery in orchard 2 was $100 \%$ for Diaporthe sp. (STEU 7837), D. foeniculina (STEU 7836), and D. infecunda.

In the green shoot trial, inoculations performed similarly to those of mature wood inoculations. Thus, significant differences $(P<$ 0.0001 ) in mean lesion lengths caused by the different isolates were evident between the orchards, with orchard 2 displaying higher mean lesion lengths compared with orchard 1 . Lesion lengths produced by the different isolates were longer than those of the control in orchard 2, whereas in orchard 1, Eutypa lata (STEU 7818) and D. foeniculina (STEU 7835) produced lesions that were similar to those of the control. Diaporthe sp. (STEU 7837) was the most pathogenic isolate and D. foeniculina (STEU 7835) was the least pathogenic isolate in orchard 1. In orchard 2, P. parasiticum (STEU 7824) and D. foeniculina (STEU 7833) were the most and least pathogenic, respectively. Mean lesion lengths produced by the different fungal isolates as well as the control for both orchards are presented in Table 2.

The percentage recovery of fungal isolates from green shoots in orchard 1 ranged from $50 \%$ for both Eutypa lata isolates, E. citricola (STEU 7815, STEU 7816), and D. mutila to $100 \%$ for all D. foeniculina isolates, Diaporthe sp. (STEU 7838 and STEU 7842), N. australe (STEU 7830, STEU 7832), P. scolyti (STEU 7820, STEU 7822), $P$. minimum, $P$. parasiticum (STEU 7821), and $P$. australiense. In orchard 2, lowest recovery percentages were obtained for E. citricola isolate STEU 7816 (10\%), Diplodia seriata isolate STEU 7825 (30\%), E. microtheca (30\%), and E. citricola isolate STEU 7815 (40\%). Highest percentage recovery of $100 \%$ was obtained for isolates including D. foeniculina (STEU 7835), Diaporthe sp. (STEU 7837), all isolates of Phaeoacremonium species, and N. australe (STEU 7829).

\section{Discussion}

The aim of this study was to identify trunk disease fungi associated with persimmon orchards and to investigate their possible role as pathogens. The study revealed that a number of lignocolous fungi are associated with infected pruning wounds, cankers as well as dieback symptoms on persimmon. Fungal species were abundantly isolated from dark black lesions occurring between diseased and healthy tissues of pruning wounds as well as along cankers. Often, different species co-occurred in a single symptom, suggesting that the etiology of symptoms observed may be complex, which makes elucidation of the real cause of the symptoms difficult. New knowledge generated from this research will form the basis for future studies that are needed on persimmon, as persimmon production is expected to expand in South Africa (Claassen 2015).

The most predominant fungal taxa isolated from symptomatic wood of persimmon trees in this study belonged to the order Diaporthales. This order consists of several species that are endophytes and plant pathogens causing cankers, blights, and dieback on a wide range of hosts world wide (Gomes et al. 2013; Udayanga et al. 2011). There have been a few reports on the occurrence of Diaporthales species on

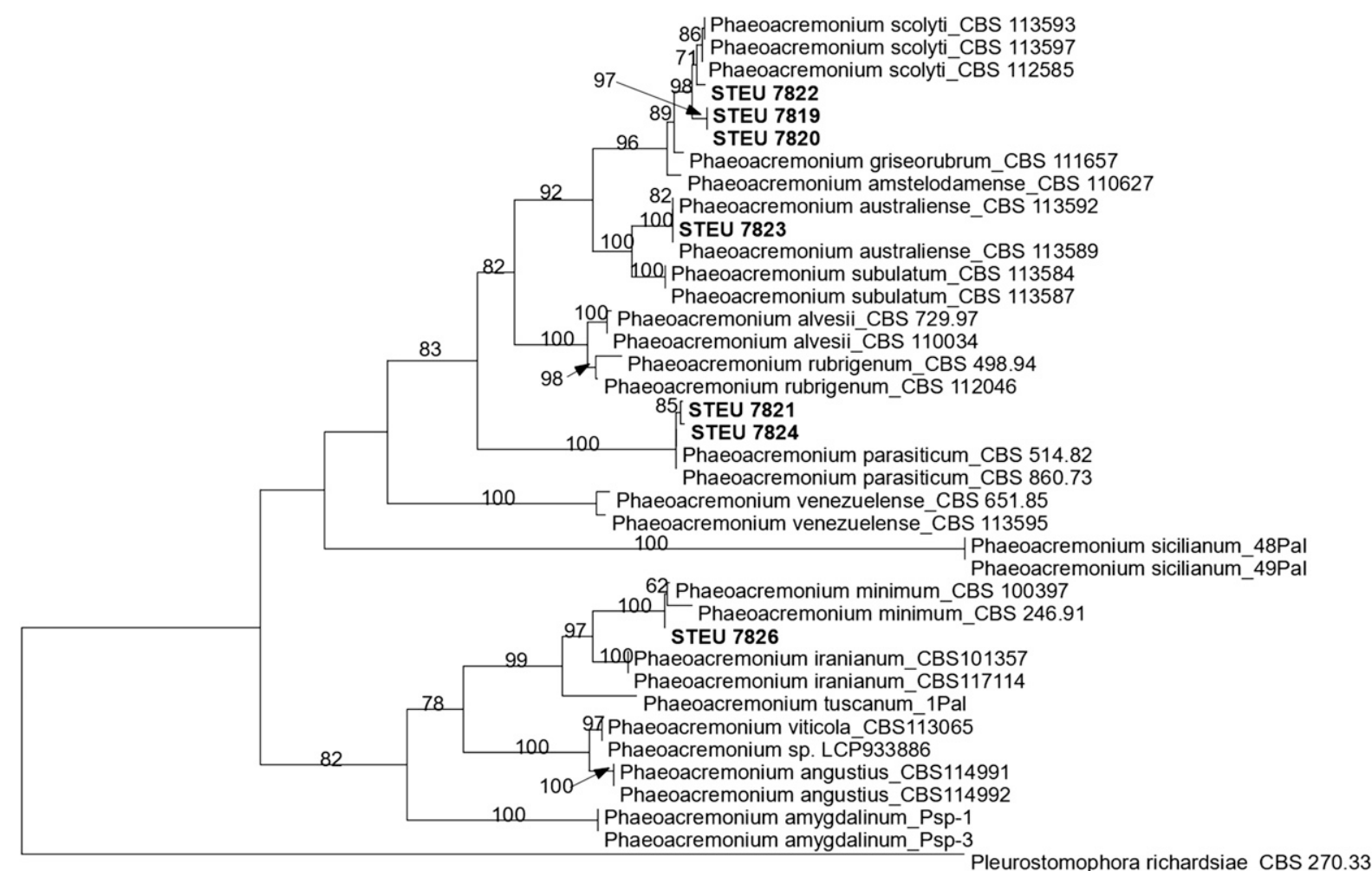

0.2

Fig. 5. Maximum likelihood phylogenetic tree of Togniniaceae species based on $\beta$-tubulin and actin sequence data. Bootstrap support values were calculated from 1,000 replicates and bootstrap support values $<60 \%$ are not shown. Pleurostomophora richardsiae was used as an outgroup and isolates obtained in the current study are in bold. 
persimmon worldwide. Diaporthe foeniculina (formerly D. neotheicola) was the most abundant species isolated in this study, and it has been reported to cause shoot blight of persimmon in Australia (Golzar et al. 2012). Other species that have been reported elsewhere include Phomopsis diospyri, which has been found to cause shoot blight and dieback in Greece (Thomidis and Navrozidis 2009), whereas Phomopsis mali was reported as causing severe dieback in persimmon in Italy (Rosciglione and Ciraulo 1983). Kitagawa and

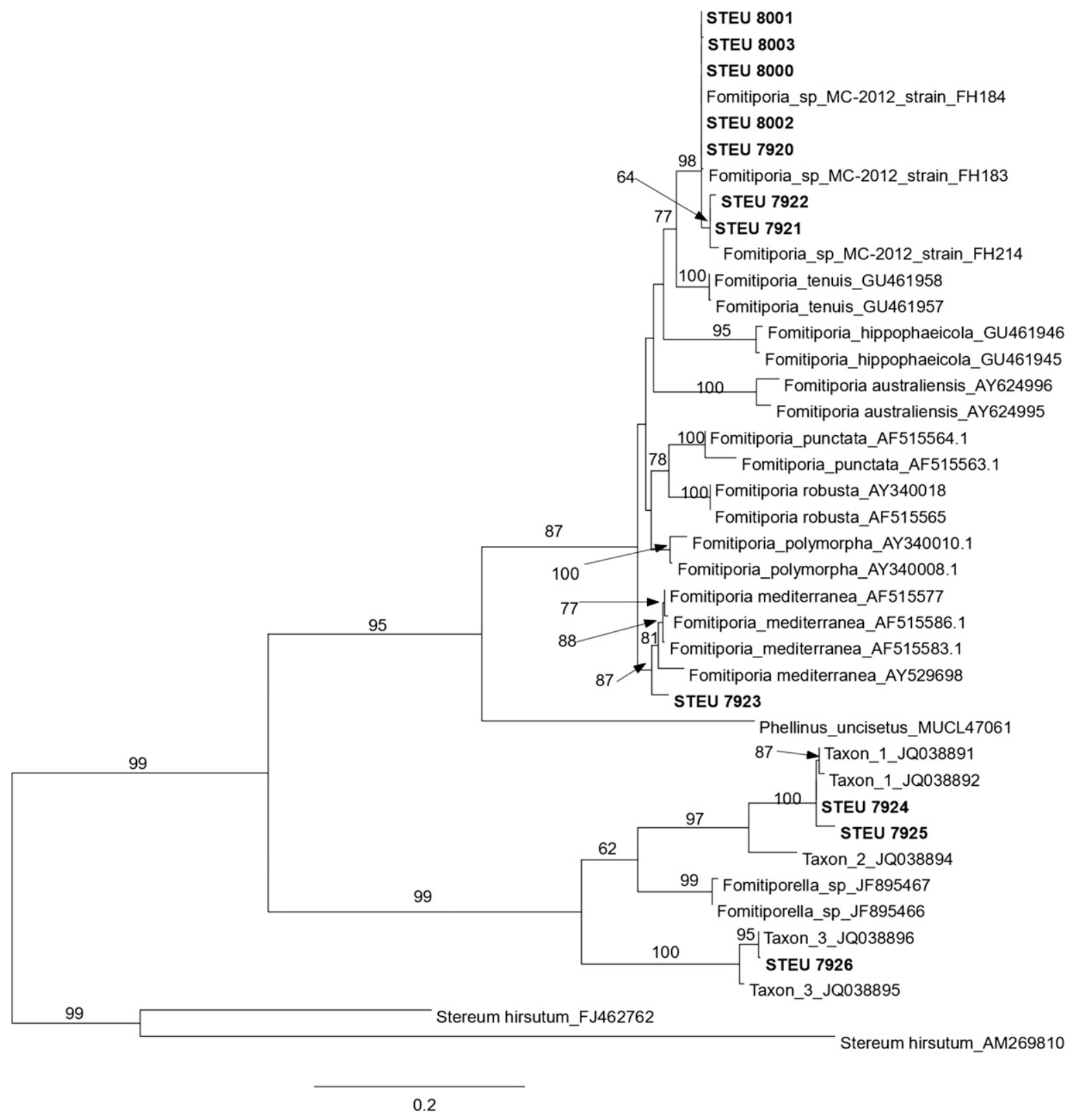

Fig. 6. Maximum likelihood phylogenetic tree of species in family Hymenochaetaceae based on internal transcribed spacer sequence data. Bootstrap support values were calculated from 1,000 replicates and bootstrap support values $<60 \%$ are not shown. Two isolates of Stereum hirsutum were used as outgroups and isolates obtained in the current study are in bold.
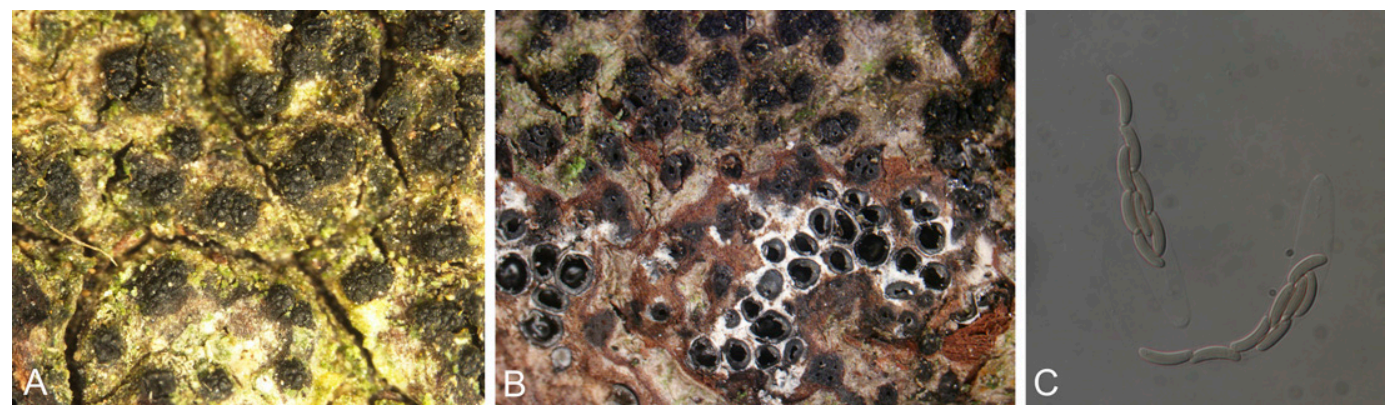

Fig. 7. Morphology of Eutypella citricola from persimmon (Diospyros kaki). A, Stromata aggregated on bark surface with apparent sulcate ostioles protruding on stroma surface. B, Perithecia surrounded by powdery entostroma. C, Clavate, octosporous asci with allantoid ascospores. 
Glucina (1984) also reported on Phomopsis spp. causing cankers on persimmon in Japan. Four other species belonging to order Diaporthales were isolated for the first time from persimmon wood in this study, namely $D$. eres, $D$. infecunda, D. ambigua, and Diaporthe sp. Diaporthe species have been reported to cause diseases on several important crops in different areas of the world, and pathogenicity results in this study add persimmon as an additional host to which these species are pathogenic. For example, D. ambigua has been associated with stem cankers on blueberry in Chile (Elfar et al. 2013) and cankers on grapevine as well as apricot in California (Lawrence et al. 2015). In South Africa, D. ambigua and $D$. foeniculina have been associated with cankers of crops including pome fruits and grapevines (Cloete et al. 2011; Smit et al. 1996; van Niekerk et al. 2005; White et al. 2011b). The relationships within the clade containing $D$. amydgali, D. ovoicicola, and $D$. fusicola could not be resolved using the two gene areas used in the current study. A previous study was able to reconstruct the relationships by sequencing multiple gene regions (Gao et al. 2014) and, thus, it is likely that these can be resolved by use of more gene areas.

Diatrypaceae species were the second most predominant fungi to be isolated from cankers and pruning wounds of persimmon trees in the current study and they included Eutypa lata, E. citricola, and E. microtheca. The most dominant species was Eutypella citricola, whereas Eutypa lata and E. microtheca were not frequent. Eutypa lata has been reported on more than 130 hosts, including persimmon. Eutypella citricola has only been reported on 13 hosts in Argentina, Australia, Brazil, China, Ghana, and The Philippines, whereas $E$. microtheca has only been reported from three hosts in Australia (Farr and Rossman 2015). Both E. citricola and E. microtheca are first reports on persimmon. The pathogenicity trial in the present study showed that isolates of the Diatrypaceae species were pathogenic on persimmon, since they produced lesions significantly different from the control, with the exception of two isolates, Eutypa lata (STEU 7818) and E. citricola (STEU 7813), whose lesions were similar to those of the control on green shoots and mature wood, respectively, in orchard 1. The low incidence of Eutypa lata in persimmon is curious, because this species has been abundantly isolated from several fruit trees (Trouillas et al. 2011). Vineyards and orchards, including persimmon, are cultivated in close proximity in South Africa, and one would assume that these serve as inoculum reservoirs for each other. Trouillas et al. (2011) isolated a number of diatrypaceous fungi including Eutypa lata, E. citricola, and E. microtheca from native and fruit trees around vineyards and suggested that these served as inoculum sources to vineyards and vice versa. The rare isolation of Eutypa lata and E. microtheca in this study, compared with E. citricola, may also suggest that they are currently not major pathogens on persimmon in South Africa. Eutypa lata is frequently associated with dieback of grapevines in South African vineyards that are 10 years and older (White et al. 2011a). Ferreira et al. (1989) regarded Eutypa lata as the most probable cause of this dieback phenomenon in South African vineyards.

The Botryosphaeriaceae spp. represent the third most abundant pathogen group isolated in this study. Fungal taxa in the family

Table 2. Pathogenicity tests listing the isolates and their mean lesion lengths on mature wood and green shoots of persimmon after four months of incubation ${ }^{\mathrm{v}}$

\begin{tabular}{|c|c|c|c|c|c|}
\hline \multirow[b]{3}{*}{ Species identity } & \multirow[b]{3}{*}{ Accession number } & \multicolumn{4}{|c|}{ Mean lesion length (mm) } \\
\hline & & \multicolumn{2}{|c|}{ Mature wood } & \multicolumn{2}{|c|}{ Green shoots } \\
\hline & & Orchard 1 & Orchard 2 & Orchard 1 & Orchard 2 \\
\hline Eutypa lataw $^{\mathrm{w}}$ & STEU 7817 & 40.25 bcdefghi & 44.04 bcdef & 36.54 bcdefgh & $37.81 \mathrm{defg}$ \\
\hline E. lata $^{\mathrm{w}}$ & STEU 7818 & 37.03 defghi & 50.29 bcde & $27.83 \mathrm{hi}$ & 45.88 abcdef \\
\hline Eutypella citricola ${ }^{\mathrm{x}}$ & STEU 7813 & 33.98 fghij & 48.36 bcdef & 37.69 bcdefgh & 43.09 abcdef \\
\hline E. citricola $^{\mathrm{w}}$ & STEU 7815 & 43.34 abcdefg & 39.45 def & 30.89 efgh & 46.31 abcde \\
\hline E. citricola $^{\mathrm{x}}$ & STEU 7816 & 33.30 cdefghi & 41.54 cdef & 30.51 efgh & 36.96 defg \\
\hline E. microtheca ${ }^{\mathrm{w}}$ & STEU 7814 & $53.92 \mathrm{a}$ & $51.95 \mathrm{bcd}$ & $48.36 \mathrm{ab}$ & $33.89 \mathrm{fg}$ \\
\hline Diaporthe foeniculina ${ }^{\mathrm{y}}$ & STEU 7833 & $49.02 \mathrm{abc}$ & 46.78 bcdef & 42.45 abcde & $30.41 \mathrm{~g}$ \\
\hline D. foeniculina $a^{\mathrm{x}}$ & STEU 7835 & 31.76 ghij & $36.71 \mathrm{fg}$ & $27.20 \mathrm{hi}$ & 42.09 abcdefg \\
\hline D. foeniculin $\mathrm{x}^{\mathrm{x}}$ & STEU 7836 & 42.13 abcdefghi & $45.05 \mathrm{bcdef}$ & 32.38 cdefgh & $52.40 \mathrm{a}$ \\
\hline Diaporthe sp. ${ }^{\mathrm{x}}$ & STEU 7837 & $49.53 \mathrm{ab}$ & 51.18 bcde & $52.41 \mathrm{a}$ & 42.68 abcdef \\
\hline Diaporthe sp. ${ }^{\mathrm{x}}$ & STEU 7838 & 41.36 bcdefghi & $54.34 \mathrm{ab}$ & 41.47 abcdef & $36.51 \mathrm{efg}$ \\
\hline Diaporthe sp. ${ }^{\mathrm{w}}$ & STEU 7842 & 48.42 abcd & 45.28 bcdef & 42.27 abcde & 46.28 abcde \\
\hline D. ambigua $^{\mathrm{x}}$ & STEU 7840 & 41.34 bcdefghi & $43.10 \mathrm{bcdef}$ & 31.62 cdefgh & 40.03 bcdefg \\
\hline D. eres ${ }^{\mathrm{w}}$ & STEU 7841 & 42.64 abcdefgh & $42.91 \mathrm{bcdef}$ & 33.96 cdefgh & 42.33 abcdefg \\
\hline D. infecunda ${ }^{\mathrm{w}}$ & STEU 7839 & $30.68 \mathrm{ij}$ & 47.12 bcdef & 35.32 bcdefgh & $49.92 \mathrm{abc}$ \\
\hline Diplodia seriata ${ }^{\mathrm{x}}$ & STEU 7825 & 42.39 abcdefghi & $41.51 \mathrm{cdef}$ & 36.67 bcdefgh & 37.98 cdefg \\
\hline D. seriata $^{\mathrm{x}}$ & STEU 7827 & 38.45 bcdefghi & 42.86 bcdef & $28.65 \mathrm{fgh}$ & 42.67 abcdef \\
\hline D. seriata $\mathrm{z}$ & STEU 7828 & 36.89 defghi & 45.51 bcdef & 38.37 bcdefgh & 37.82 defg \\
\hline D. mutila ${ }^{\mathrm{x}}$ & STEU 7834 & 41.01 bcdefghi & $52.52 \mathrm{abc}$ & $28.32 \mathrm{hg}$ & $48.69 \mathrm{abcd}$ \\
\hline Neofusicoccum australe ${ }^{\mathrm{z}}$ & STEU 7829 & 36.27 efghi & 42.25 bcdef & 37.65 bcdefgh & 46.58 abcde \\
\hline N. australe ${ }^{\mathrm{x}}$ & STEU 7830 & 30.70 hij & 48.97 bcdef & 41.67 abcdef & 46.95 abcde \\
\hline N. australe ${ }^{\mathrm{x}}$ & STEU 7831 & 43.73 abcdef & $52.32 \mathrm{bc}$ & 44.45 abcd & $48.87 \mathrm{abcd}$ \\
\hline N. parvum $^{\mathrm{x}}$ & STEU 7831 & 48.01 abcde & 51.62 bcde & $47.32 \mathrm{ab}$ & $52.76 \mathrm{a}$ \\
\hline Phaeoacremonium scolyti ${ }^{\mathrm{y}}$ & STEU 7819 & 44.55 abcdef & 43.80 bcdef & 38.27 bcdefgh & 44.75 abcdef \\
\hline P. scolyti ${ }^{\mathrm{w}}$ & STEU 7820 & 46.15 abcde & 39.07 ef & $44.63 \mathrm{abc}$ & 44.87 abcdef \\
\hline P. scolyti ${ }^{\mathrm{w}}$ & STEU 7822 & 43.41 abcdefg & 48.54 bcdef & 31.45 defgh & 37.82 defg \\
\hline$P$. parasiticum ${ }^{\mathrm{y}}$ & STEU 7821 & 43.55 abcdefg & 49.12 bcdef & 37.36 bcdefgh & $52.70 \mathrm{a}$ \\
\hline P. parasiticum $^{\mathrm{w}}$ & STEU 7824 & $49.28 \mathrm{ab}$ & $53.95 \mathrm{abc}$ & $44.11 \mathrm{abcd}$ & $53.96 \mathrm{a}$ \\
\hline P. australiense $e^{\mathrm{w}}$ & STEU 7823 & 44.59 abcdef & $65.17 \mathrm{a}$ & 40.90 abcdefg & 43.42 abcdef \\
\hline P. minimum $^{\mathrm{w}}$ & STEU 7826 & 46.60 abcde & 45.39 bcdef & 41.98 abcde & $51.90 \mathrm{ab}$ \\
\hline Agar plug & - & $22.60 \mathrm{j}$ & $26.18 \mathrm{~g}$ & $15.13 \mathrm{i}$ & $13.98 \mathrm{~h}$ \\
\hline LSD value & - & 11.95 & $12.75^{\circ}$ & 13.07 & 12.09 \\
\hline
\end{tabular}

${ }^{v}$ Means followed by the same letter in the same column are not significantly different $(P<0.05)$.

w Isolated from the black line along the length of canker.

${ }^{x}$ Isolated from the black margin between necrotic and healthy tissue below pruning wound.

y Isolated from black streaks extending from the black margin of dead and healthy tissue below pruning wound.

$\mathrm{z}$ Isolated from brown discoloration surrounded by black margins. 
Botryosphaeriaceae occur on a wide range of woody plants and, although many species have been characterized as endophytes in symptomless tissues, many are important pathogens in several crops. Only two Botryosphaeriaceae species have been reported on persimmon wood, namely N. parvum in New Zealand (Gadgil 2005; Pennycook 1989) and Diplodia seriata in the United States (United States Department of Agriculture 1960). To the knowledge of the authors, D. mutila and $N$. australe have not been reported on persimmon before this study and, thus, they are first reports on persimmon worldwide. Overall, the current study found all the species in this group to be pathogenic on both mature wood and green shoots, with the exception of one isolate of $N$. australe (STEU 7830) that produced lesions not significantly different from the control in the mature wood inoculation in orchard 1. Our results support similar studies conducted on other hosts, for example $N$. parvum, D. mutila, and N. australe were reported to be highly pathogenic on grapevine shoots in South Africa (van Niekerk et al. 2004). Phillips (1998) also found $D$. mutila to be pathogenic on grapevine in Portugal. Conflicting reports on the virulence of Diplodia seriata exist in literature. For example, Diplodia seriata was found to be less virulent compared with other Botryosphaeriaceae species when inoculated on grapevines shoots (Phillips 1998; Taylor et al. 2005; van Niekerk et al. 2004) and on olive trees (Úrbez-Torres et al. 2013), although it produced lesions significantly longer than the controls. On the other hand, Larignon et al. (2001) and Auger et al. (2004) reported Diplodia seriata to be highly virulent, causing black dead arm on grapevine. The differences in virulence could be attributed to variation within a species or the use of different grapevine cultivars for pathogenicity tests. Lesions produced by Diplodia seriata in this study were statistically similar to those produced by other Botryosphaeriaceae species investigated. This indicates that either persimmon is more susceptible to Diplodia seriata or the isolates found on persimmon in South Africa are more virulent than those previously found by other studies on grapevine (Phillips 1998; Taylor et al. 2005; van Niekerk et al. 2004).

Additional trunk pathogens isolated in low numbers in this study include pathogens belonging to family Togniniaceae. These pathogens are associated with Petri disease and esca of grapevines (Mostert et al. 2006). At the moment, the Togniniaceae species $P$. minimum (formerly P. aleophilum), $P$. parasiticum, $P$. scolyti, and $P$. australiense only occur on 13,13, eight, and two woody hosts, respectively (Gramaje et al. 2015; Marín-Terrazas et al. 2016), and hence, this study adds persimmon as an additional host for these species. All Phaeoacremonium species in this study were pathogenic on persimmon tissues. Another Phaeoacremonium species that has been reported on persimmon is $P$. rubrigenum in Iran (Jamali and Banihashemi 2012).

The Hymenochaetaceae spp., which are involved in the development of white rot in a number of trees as well as esca of grapevines (Cloete et al. 2015a), were also found to occur on persimmon in this study. Fomitiporia species have been reported to cause decay in crops, including citrus trees (Elena et al. 2006), kiwifruit (Di Marco et al. 2004; Elena and Paplomatas 2002), and grapevines (Cloete et al. 2015b; Fischer 2006). The decay fungi isolated in this study, which include F. capensis, Fomitiporia sp., Fomitiporella sp., and Inocutis sp. (Cloete et al. 2014, 2015b) are reported for the first time on persimmon worldwide. These isolates were not included in the pathogenicity trials because of the length of time required to produce wood decay in plant tissues inoculated with basidiomycetous fungi as well as to reisolate the fungi from inoculated tissues (Cloete et al. 2015b). Di Marco et al. (2004) were not able to reisolate F. mediterranea from inoculated canes of kiwifruit six months after inoculation, although Cloete et al. (2015b) demonstrated that $F$. capensis can cause white rot symptoms in grapevine within 24 months.

Overall, all the fungal taxa colonized mature wood better in relation to green shoots. This might suggest that the taxa are woodinhabiting fungi rather than green shoot pathogens. Furthermore, in both experiments, the isolates produced longer lesions in orchard 2, whose trees are grafted on the rootstock Diospyros virginiana, compared with orchard 1, whose trees are grafted on Diospyros kaki. Therefore, it seems that rootstock type might influence the susceptibility or tolerance of persimmon trees to trunk disease colonization. Trees grafted on Diospyros kaki have tolerance, to some extent, to trunk disease pathogen colonization, compared with Diospyros virginiana. Cohen et al. (1991) observed poor growth and several decline symptoms on persimmon trees ('Triumph') grafted on Diospyros virginiana, whereas no decline was observed on trees grafted on Diospyros kaki in Israel. Diospyros $k a k i$ is generally compatible with many cultivars during grafting (Bellini 2002; Hodgson 1940) and is less susceptible to diseases such as crown gall, compared with Diospyros virginiana (Bellini 2002).

Only fruiting bodies of $E$. citricola were found in this study, probably because they can easily be observed on wood. Fruiting bodies of trunk pathogens such as $P$. minimum and Diplodia seriata have previously been found on grapevines (Baloyi et al. 2013; RooneyLatham et al. 2005). Fruiting bodies of E. microtheca and Eutypa lata have also been found on several woody hosts, including grapevine (Trouillas and Gubler 2010; Trouillas et al. 2011). It is possible that spores of these pathogens are dispersed from grapevine to persimmon or vice versa, in particular if these hosts are in close proximity, as in the case of the farms surveyed in the study.

The association of trunk pathogens with cankers and subsequent dieback of several woody hosts has been widely studied as described above. However, to date, only a few studies have reported on trunk pathogens affecting persimmon. These and our report indicate that trunk disease fungi may be important pathogens of persimmon, although the extent to which the pathogens could hinder plant productivity is yet to be determined. However, this is the first study to identify a number of taxonomically unrelated fungi as pathogenic to persimmon.

This research is the first to determine trunk disease pathogens associated with persimmon trees in the Western Cape of South Africa. The information obtained from this study provides the local persimmon industry with knowledge on the occurrence of trunk disease pathogens, forms a baseline for more research, and provides farmers with additional tools to manage trunk diseases. Additionally, this study is of significant importance to the major fruit industries, as persimmon could potentially be an important alternative host that needs to be taken into consideration when managing trunk disease pathogens.

\section{Acknowledgments}

The authors acknowledge funding received from the Agricultural Research Council (ARC), National Research Foundation (NRF), Technology and Human Resources for Industry Programme (THRIP), and Department of Plant Pathology, University of Stellenbosch. Statistical analyses were performed by M. Van Der Rijst of the ARC (Biometry Unit). We greatly appreciate P. Lesuthu, I. Du Plessis, M. Knipe, L. Williams, L. Maart, P. Maharaj, J. Marais, D. Marais, and C. Vermeulen of the ARC-Infruitec-Nietvoorbij for technical assistance.

\section{Literature Cited}

ARISA. 2015. Fruit industry. Agricultural Resources in South Africa, Western Cape, South Africa. Published online. http://www.sharon-fruit.com/about-us/ sharon-fruit-industry

Auger, J., Esterio, M., Ricke, G., and Pérez, I. 2004. Black dead arm and basal canker of Vitis vinifera cv. Red globe caused by Botryosphaeria obtusa in Chile. Plant Dis. 88:1286.

Baloyi, M. A., Halleen, F., Mostert, L., and Eskalen, A. 2013. First report of Togninia minima perithecia on esca- and petri-diseased grapevines in South Africa. Plant Dis. 97:1247.

Bellini, E. 2002. Cultural practices for persimmon production. Pages 39-52 in: First Mediterranean symposium on persimmon. No. 51. E. Bellini and E. Giordani, eds. CIHEAM, Zaragoza, Spain.

Carbone, I., and Kohn, L. M. 1999. A method for designing primer sets for speciation studies in filamentous ascomycetes. Mycologia 91:553-556.

Carlucci, A., Lops, F., Cibelli, F., and Raimondo, M. L. 2015. Phaeoacremonium species associated with olive wilt and decline in southern Italy. Eur. J. Plant Pathol. 141:717-729.

Claassen, J. 2015. SA Sharon fruit: Growing local and export sales. Farmers Weekly. Published online. http://www.farmersweekly.co.za/article.aspx?id= 74424\&h=SASharonfruit:growinglocalandexportsales

Cloete, M., Fischer, M., Mostert, L., and Halleen, F. 2014. A novel Fomitiporia species associated with esca on grapevine in South Africa. Mycol. Prog. 13:303-311.

Cloete, M., Fischer, M., Mostert, L., and Halleen, F. 2015a. Hymenochaetales associated with esca-related wood rots on grapevine with a special emphasis on the status of esca in South African vineyards. Phytopathol. Mediterr. 54:299-312.

Cloete, M., Fourie, P. H., Damm, U., Crous, P. W., and Mostert, L. 2011. Fungi associated with die-back symptoms of apple and pear trees, a possible inoculum source of grapevine trunk disease pathogens. Phytopathol. Mediterr. 50 (Suppl.):S176-S190. 
Cloete, M., Mostert, L., Fischer, M., and Halleen, F. 2015b. Pathogenicity of South African Hymenochaetales taxa isolated from esca-infected grapevines. Phytopathol. Mediterr. 54:368-379.

Cohen, Y., Gur, A., Barkai, Z., and Blumenfeld, A. 1991. Decline of persimmon (Diospyros kaki L.) trees on Diospyros virginiana rootstocks. Sci. Hortic.Amsterdam 48:61-70.

Crous, P. W., Phillips, A. J. L., and Baxter, A. P. 2000. Phytopathogenic fungi from South Africa. Stellenbosch University Department of Plant Pathology Press, Matieland, South Africa.

Damm, U., Mostert, L., Crous, P. W., and Fourie, P. H. 2008. Novel Phaeoacremonium species associated with necrotic wood of Prunus trees. Persoonia 20:87-102.

Di Marco, S., Calzarano, F., Osti, F., and Mazzullo, A. 2004. Pathogenicity of fungi associated with a decay of kiwifruit. Australas. Plant Pathol. 33:337-342.

Elena, K., Fischer, M., Dimou, D., and Dimou, D. M. 2006. Fomitiporia mediterranea infecting citrus trees in Greece. Phytopathol. Mediterr. 45:35-39.

Elena, K., and Paplomatas, E. J. 2002. First report of Fomitiporia punctata infecting kiwifruit. Plant Dis. 86:1176.

Elfar, K., Torres, R., Díaz, G. A., and Latorre, B. A. 2013. Characterization of Diaporthe australafricana and Diaporthe spp. associated with stem canker of blueberry in Chile. Plant Dis. 97:1042-1050.

English, H., and Davis, I. R. 1978. Eutypa armeniacae in Apricot: Pathogenesis and induction of xylem soft rot. Hilgardia 46:193-204.

Eskalen, A., Feliciano, J., and Gubler, W. D. 2007. Susceptibility of grapevine pruning wounds and symptom development in response to infection by Phaeoacremonium aleophilum and Phaeomoniella chlamydospora. Plant Dis. 91:1100-1104.

Farr, D. F., and Rossman, A. Y. 2015. Fungal databases. United States Department of Agriculture Agricultural Research Service, Washington, DC. Published online. http://nt.ars-grin.gov/fungaldatabases.

Ferreira, J. H. S., Matthee, F. N., and Thomas, A. C. 1989. Fungi associated with dieback and pruning wounds of grapevines in South Africa. S. Afr. J. Enol. Vitic. 10:62-66.

Fischer, M. 2006. Biodiversity and geographic distribution of basidiomycetes causing esca-associated white rot in grapevine: A worldwide perspective. Phytopathol. Mediterr. 45 (Suppl):S30-S42.

Gadgil, P. D. 2005: Fungi on trees and shrubs in New Zealand. In: Fungi of New Zealand Fungal Diversity Research Series 16. Fungal Diversity Press, Hong Kong.

Gao, Y., Su, Y., Sun, W., and Cai, L. 2014. Diaporthe species occurring on Lithocarpus glabra in China, with descriptions of five new species. Fungal Biol. 119:295-309.

Glass, N. L., and Donaldson, G. C. 1995. Development of primer sets designed for use with the PCR to amplify conserved genes from filamentous ascomycetes. Appl. Environ. Microbiol. 61:1323-1330.

Glawe, D. A., and Rogers, J. D. 1984. Diatrypaceae in the Pacific NORTHWEST. Mycotaxon 20:401-460.

Golzar, H., Tan, Y. P., Shivas, R. G., and Wang, C. 2012. First report of shoot blight of persimmon caused by Diaporthe neotheicola in Australia. Australas. Plant Dis. 7:115-117.

Gomes, R. R., Glienke, C., Videira, S. I. R., Lombard, L., Groenewald, J. Z., and Crous, P. W. 2013. Diaporthe: A genus of endophytic, saprobic and plant pathogenic fungi. Persoonia 31:1-41.

Gramaje, D., Agustí-Brisach, C., Pérez-Sierra, A., Moralejo, E., Olmo, D., Mostert, L., Damm, U., and Armengol, J. 2012. Fungal trunk pathogens associated with wood decay of almond trees on Mallorca (Spain). Persoonia 28:1-13.

Gramaje, D., Mostert, L., Groenewald, J. Z., and Crous, P. W. 2015. Phaeoacremonium: From esca disease to phaeohyphomycosis. Fungal Biol. 119:759-783.

Guindon, S., and Gascuel, O. 2003. A simple, fast, and accurate algorithm to estimate large phylogenies by maximum likelihood. Syst. Biol. 52:696-704.

Hodgson, R. W. 1940. Rootstocks for the Oriental Persimmon. Pages 338-339 in: Proceedings, American Society for Horticultural Science, 1939, Vol. 3.

Jamali, S., and Banihashemi, Z. 2012. First report of Phaeoacremonium rubrigenum, associated with declining persimmon trees in Iran. J. Crop Prot. 1:153-159.

Katoh, K., Misawa, K., Kuma, K., and Miyata, T. 2002. MAFFT: A novel method for rapid multiple sequence alignment based on fast Fourier transform. Nucleic Acids Res. 30:3059-3066.

Kearse, M., Moir, R., Wilson, A., Stones-Havas, S., Cheung, M., Sturrock, S., Buxton, S., Cooper, A., Markowitz, S., Duran, C., Thierer, T., Ashton, B., Mentjies, P., and Drummond, A. 2012. Geneious Basic: An integrated and extendable desktop software platform for the organization and analysis of sequence data. Bioinformatics 28:1647-1649.

Kitagawa, H., and Glucina, P. G. 1984. Persimmon culture in New Zealand. Government Printer, Wellington, New Zealand.

Larignon, P., Fulchic, R., Cere, L., and Dubos, B. 2001. Observation on black dead arm in French vineyards. Phytopathol. Mediterr. 40 (Suppl.):S336-S342.

Lawrence, D. P., Travadon, R., and Baumgartner, K. 2015. Diversity of Diaporthe species associated with wood cankers of fruit and nut crops in northern California. Mycologia 107:926-940.

Llácer, G., and Badenes, M. L. 2002. Persimmon production and market. Pages 9-21 in: Options Méditerranéennes: Série A. Séminaires Méditerranéens, no. 51. E. Bellini and E. Giordani, eds. CIHEAM, Zaragoza, Spain.

Makatini, G. J. 2014. The role of sucker wounds as portals for grapevine trunk pathogen infections. Masters thesis. Stellenbosch University, Matieland, South Africa.

Marín-Terrazas, M., Ramos-Sáez de Ojer, J. L., López-Manzanares, B., and Gramaje, D. 2016. First report of Phaeoacremonium minimum causing wood decay in nursery plants of almond in Spain. Plant Dis. 100:1244.
Moller, W. J., and Kasimatis, A. N. 1981. Further evidence that Eutypa armeniacae - not Phomopsis viticola - Incites dead arm symptoms on grape. Plant Dis. 65:429-431.

Mostert, L., Crous, P. W., Kang, J.-C., and Phillips, A. J. L. 2001. Species of Phomopsis and a Libertella sp. occurring on grapevines with specific reference to South Africa: Morphological, cultural, molecular and pathological characterization. Mycologia 93:146-167.

Mostert, L., Groenewald, J. Z., Gams, W., Summerbell, R. C., and Crous, P. W. 2006. Taxonomy and pathology of Togninia (Diaporthales) and its Phaeoacremonium anamorphs. Stud. Mycol. 54:1-113.

Moyo, P., Allsopp, E., Roets, F., Mostert, L., and Halleen, F. 2014. Arthropods vector trunk disease pathogens. Phytopathology 104:1063-1069.

Nunez, C., and Bruins, S. 2013. Israel: Mor International covers gaps in persimmon season. FreshPlaza, Tholen, The Netherlands. Available online: http://www.freshplaza.com/article/114793/israel-mor-international-covers-gapsin-persimmon-season

O’Donnell, K., and Cigelnik, E. 1997. Two different intragenomic rDNA ITS2 types within a monophyletic lineage of the fungus Fusarium are nonorthologous. Mol. Phylogenet. Evol. 7:103-116.

Pennycook, S. R., Young, J. M., Fletcher, M. J., and Fry, P. A. 1989. Plant diseases recorded in New Zealand. Plant Diseases Division, DSIR, Auckland, New Zealand.

Phillips, A. J. L. 1998. Botryosphaeria dothidea and other fungi associated with excoriose and dieback of grapevines in Portugal. J. Phytopathol. 146:327-332.

Rooney-Latham, S., Eskalen, A., and Gubler, W. D. 2005. Occurrence of Togninia minima perithecia in esca-affected vineyards in California. Plant Dis. 89:867-871.

Rosciglione, B., and Ciraulo, D. 1983. Observations on a severe dieback of persimmon (Diospyros kaki L.) in Sicily, caused by Phomopsis mali. Inf. Fitopatol. 33:51-54.

Slippers, B., Smit, W. A., Crous, P. W., Coutinho, T. A., Wingfield, B. D., and Wingfield, M. J. 2007. Taxonomy, phylogeny and identification of Botryosphaeriaceae associated with pome and stone fruit trees in South Africa and other regions of the world. Plant Pathol. 56:128-139.

Smit, W. A., Viljoen, C. D., Wingfield, B. D., Wingfield, M. J., and Calitz, F. J. 1996. A new canker disease of apple, pear and plum rootstocks caused by Diaporthe ambigua in South Africa. Plant Dis. 80:1331-1335.

Taylor, A., St, J., Hardy, G. E., Wood, P., and Burgess, T. 2005. Identification and pathogenicity of Botryosphaeria species associated with grapevine decline in Western Australia. Australas. Plant Pathol. 34:187-195.

Thomidis, T., and Navrozidis, E. 2009. First report of Phomopsis diospyri causing shoot blights on persimmon trees in Greece. J. Plant Pathol. 91:500.

Tous, J., and Ferguson, L. 1996. Mediterranean fruits. Pages 416-430. In: Progress in New Crops. J. Janick,ed. ASHS Press, Arlington, VA.

Trouillas, F. P., and Gubler, W. D. 2010. Host range, biological variation, and phylogenetic diversity of Eutypa lata in California. Phytopathology 100: 1048-1056.

Trouillas, F. P., Pitt, W. M., Sosnowski, M. R., Huang, R. J., Peduto, F., Loschiavo, A., Savocchia, S., Scott, E. S., and Gubler, W. D. 2011. Taxonomy and DNA phylogeny of Diatrypaceae associated with Vitis vinifera and other woody plants in Australia. Fungal Divers. 49:203-223.

Trouillas, F. P., Úrbez-Torres, J. R., and Gubler, W. D. 2010. Diversity of diatrypaceous fungi associated with grapevine canker diseases in California Mycologia 102:319-336.

Udayanga, D., Xingzhong, L., McKenzie, E. H. C., Chukeatirote, E., Bahkali, A H. A., and Hyde, K. D. 2011. The genus Phomopsis: Biology, applications, species concepts and names of common phytopathogens. Fungal Divers. 50: 189-225.

Uddin, W., Stevenson, K. L., Pardo-Schultheiss, R. A., and Rehner, S. A. 1998 Pathogenic and molecular characterization of three Phomopsis isolates from peach, plum, and Asian pear. Plant Dis. 82:732-737.

United States Department of Agriculture. 1960. Index of Plant Diseases in the United States USDA Handbook No. 165. United States Department of Agriculture, Washington, DC.

Úrbez-Torres, J. R., Peduto, F., Vossen, P. M., Krueger, W. H., and Gubler, W. D. 2013. Olive twig and branch dieback: Etiology, incidence, and distribution in California. Plant Dis. 97:231-244.

van Niekerk, J. M., Crous, P. W., Groenewald, J. Z., Fourie, P. H., and Halleen, F. 2004. DNA phylogeny, morphology and pathogenicity of Botryosphaeria species on grapevines. Mycologia 96:781-798.

van Niekerk, J. M., Groenewald, J. Z., Farr, D. F., Fourie, P. H., Halleen, F., and Crous, P. W. 2005. Reassessment of Phomopsis species on grapevines. Australas. Plant Pathol. 34:27-39.

Van Niekerk, J. M., Halleen, F., and Fourie, P. H. 2011. Temporal susceptibility of grapevine pruning wounds to trunk pathogen infection in South African grapevines. Phytopathol. Mediterr. 50 (Suppl.):S139-S150.

White, C., Halleen, F., Fischer, M., and Mostert, L. 2011b. Characterisation of the fungi associated with esca diseased grapevines in South Africa. Phytopathol. Mediterr. 50:204-223

White, C., Halleen, F., and Mostert, L. 2011a. Symptoms and fungi associated with esca in South African vineyards. Phytopathol. Mediterr. 50:236-246.

White, T. J., Bruns, T., Lee, S., and Taylor, J. 1990. Amplification and direct sequencing of fungal ribosomal RNA genes for phylogenetics. Pages 315-322 in: PCR Protocols, a guide to methods and applications. M. A. Innis, D. H. Gelfand, J. J. Sninsky, and J. White, eds. Academic, San Diego. 